\title{
PENGARUH ABSENSI FINGER PRINT TERHADAP KINERJA GURU PAI TERSERTIFIKASI DI KABUPATEN BENGKULU TENGAH
}

\section{Carona Elianur}

Kementerian Agama Bengkulu Tengah

Email: elianur.kemenag@gmail.com

\begin{abstract}
Abstrak. Absensi finger print telah digunakan pada guru-guru Pendidikan Agama Islam yang ada di bawah naungan Kementerian agama, dalam hal ini penulis merasa tertarik untuk meneliti pengaruh penerapan absensi finger print terhadap kinerja guru PAI tersertifikasi di Kabupaten Bengkulu Tengah. Rumusan Masalah dalam penelitian ini sebagai berikut: (1) Bagaimana persepsi guru PAI tersertifikasi terhadap absensi finger print di Kabupaten Bengkulu Tengah?; (2) Bagaimana kinerja guru PAI tersertifikasi di Kabupaten Bengkulu Tengah?; dan Apakah absensi finger print berpengaruh terhadap kinerja guru PAI tersertifikasi di Kabupaten Bengkulu Tengah?. Adapun hipotesis dari penelitian ini yaitu: (1) Ho : absensi finger print tidak berpengaruh terhadap kinerja guru tersertifikasi di Kabupaten Bengkulu Tengah; dan (2) Ha : absensi finger print berpengaruh terhadap kinerja guru tersertifikasi di Kabupaten Bengkulu Tengah. Penelitian ini menggunakan metode penelitian kuantitatif bersifat korelasional. Hasil penelitian ditemukan bahwa: (1) Persepsi absensi finger print guru tersertifikasi di Kabupaten Bengkulu Tengah berada pada tingkatan baik dengan rata-rata skor 138.8; (2) Kinerja guru tersertifikasi di Kabupaten Bengkulu Tengah berada pada tingkatan baik dengan rata-rata skor 112.8; dan (3) Persepsi absensi finger print tidak berpengaruh terhadap kinerja guru tersertifikasi di Kabupaten Bengkulu Tengah.
\end{abstract}

Kata kunci: Absensi finger print, kinerja guru.

\section{Pendahuluan}

\section{Latar belakang}

Teknologi saat ini telah berkembang sangat cepat dan mencakup seluruh aspek kehidupan tanpa terkecuali, semua sisi kehidupan modern ditandai dengan pemanfaatan teknologi didalamnya. Perkembangan ini juga merambah sisi pendidikan mulai dari pelaksanaan pembelajaran, sumber belajar, sampai pelaksaan proses kontrolnya, hampir tidak ada lagi yang tanpa pemanfaatan teknologi didalamnya. Peran guru yang dulu hanya satu-satunya sumber belajar, kini sudah sangat terbantu dengan adanya teknologi yang mampu menjadi sumber belajar lainnya. Salah satu tugas guru yang paling penting untuk saat ini adalah bagaimana mempersiapkan siswa untuk dapat menghadapi era kemajuan teknologi yang amat pesat.

Setiap institusi atau sekolah memiliki salah satu aspek terpenting yaitu sumber daya manusia, di sekolah sumber daya adalah guru. Sumber daya manusia yang baik dan memiliki kinerja serta produktifitas yang tinggi menjadi kunci sukses untuk berhasilnya sebuah organisasi maupun sekolah. Guru yang memiliki kinerja yang baik, salah satu aspek penilaiannya berupa kedisiplinan, guru yang memilki kedisiplinan yang tinggi sangat memungkinkan memiliki kinerja yang baik pula. Kedisiplinan disekolah dinilai menggunakan absensi bagi guru, baik itu absensi disaat masuk kerja maupun absensi disaat pulang kerja. Waktu kerja biasanya menggunakan waktu 7,5 jam setiap hari, 5 hari dalam seminggu. 
Kemajuan teknologi saat ini menuntut penggunaan teknologi dalam seluruh aspek pendidikan. Penggunaan absensi finger print merupakan salah satunya, hal ini bertujuan untuk mempermudah sistem monitoring terhadap absensi dan untuk menghindari kecurangan yang kemungkinan terjadi pada penggunaan absensi manual dengan memanfaatkan tanda tangan. Pada akhirnya diharapkan penggunaan absensi finger print ini akan berdampak pada meningkatnya kinerja guru. Guru tersertifikasi juga wajib menggunakan absensi finger print untuk penilaian kinerja pada saat pelaporan kinerja guru tersertifikasi. Pada prakteknya di daerah, khususnya daerah Bengkulu Tengah, absensi finger print ini menemui masalah-masalah tersendiri, salah satunya yaitu seringnya listik padam, sehingga absensi Finger print tidak dapat digunakan. Guru-guru yang ada di kabupaten Bengkulu Tengah belum semua tersertifikasi, masih ada sebagian guru yang belum tersertifikasi ini disebabkan berbagai macam alasan.

2. Rumusan Masalah

Rumusan Masalah dalam penelitian ini sebagai berikut:

a) Bagaimana persepsi guru PAI tersertifikasi terhadap absensi finger print di Kabupaten Bengkulu Tengah?

b) Bagaimana kinerja guru PAI tersertifikasi di Kabupaten Bengkulu Tengah?

c) Apakah absensi finger print berpengaruh terhadap kinerja guru PAI tersertifikasi di Kabupaten Bengkulu Tengah?

\section{Tinjauan Pustaka}

1. Pengertian Finger Print

Finger print sebagai bentuk presensi bagi karyawan. Presensi adalah suatu kegiatan atau rutinitas yang dilakukan oleh karyawan untuk membuktikan dirinya hadir atau tidak hadir dalam bekerja di suatu perusahaan. Presensi ini berkaitan dengan penerapan disiplin yang ditentukan oleh masing-masing perusahaan atau institusi. Menurut Heriawanto (2004), pelaksanaan pengisian daftar hadir atau absensi secara manual (hanya berupa buku daftar hadir), akan menjadikan penghambat bagi organisasi untuk memantau kedisiplinan karyawan dalam hal ketepatan waktu kedatangan dan jam pulang karyawan setiap hari. Hal tersebut di khawatirkan akan membuat komitmen karyawan terhadap pekerjaan dan organisasi menjadi berkurang.

Widhyarini (2010) mengatakan bahwa teknologi fingerprint adalah alat untuk memudahkan para pegawai dalam melakukan presensi dan juga menghindari adanya manipulasi data presensi yang sangat mudah dilakukan apabila presensi masih dilakukan secara manual. Sampai saat ini dan untuk masa yang akan datang fingerprint merupakan salah satu cara yang paling aman karena fingerprint tidak bisa dimanipulasi. Hal ini dapat dilihat pada sifat yang dimiliki oleh sidik jari, antara lain: (Widhyarini, 2010)

a) Perennial nature, yaitu guratan-guratan padasidik jari yang melekat pada kulit manusia seumur hidup.

b) Immutability, yaitu sidik jari seseorang tidak pernah berubah, kecuali mendapatkan kecelakaan yang serius.

c) Individuality, pola sidik jari adalah unik dan berbeda untuk setiap orang.

Sidik jari dapat digunakan sebagai sistem identifikasi yang dapat digunakan dalam aplikasi teknologi informasi seperti:

a) Access System Security, yaitu akses untuk masuk ke suatu area atau ruangan tertentu yang restricted. 
b) Authentification System, yaitu untuk akses datayang sifatnya rahasia dan terbatas (misalnya data pada perbankan, militer dan diplomatik).

\section{Kinerja}

Kinerja adalah tingkat keberhasilan seseorang atau kelompok orang dalam melaksanakan tugas dan tanggung jawabnya serta kemampuan untuk mencapai tujuan dan standar yang telah ditetapkan (Sulistyorini, 2001). Sedangkan ahli lain berpendapat bahwa kinerja merupakan hasil dari fungsi pekerjaanatau kegiatan tertentu yang di dalamnya terdiri dari tiga aspek yaitu: Kejelasan tugas atau pekerjaan yang menjadi tanggung jawabnya; Kejelasan hasil yang diharapkan dari suatu pekerjaan atau fungsi; Kejelasan waktu yang diperlukan untuk menyelesikan suatu pekerjaan agar hasil yang diharapkan dapat terwujud (Tempe, A Dale, 1992:12). Kinerja menurut Mohamad, et.al. (2004:71), adalah gambaran mengenai tingkat pencapaian pelaksanaan suatu kegiatan/program/kebijaksanaan dalam mewujudkan sasaran; tujuan; misi dan visi organisasi.

Mohamad, et.al. (2004:72), menyebutkan bahwa pengukuran kinerja merupakan suatu alat manajemen yang digunakan untuk meningkatkan kualitas pengambilan keputusan dan akuntabilitas. Pengukuran Kinerja juga digunakan untuk menilai pencapaian tujuan dan sasaran (goal and objectives). Komisi Nasional Pendidikan (2002:17) memberikan pengertian kinerja sebagai succesful role achievement yang diperoleh seseorang dari perbuatannya.

Simamora (2006) menyatakan penilaian kinerja adalah proses yang mengukur kinerja karyawan. Pemilaian pada umumnya mencakup aspek kualitatif dan kuantitatif dari kinerja ataupelaksanaan pekerjaan. Pendapat tersebut sesuai dengan apa yang dikemukakan oleh Handoko (2001: 135) yaitu performance appraisal adalah suatu proses melalui mana organisasi-organisasi mengevaluasi atau menilai prestasi kerja karyawan. Selanjutnya dikatakan bahwa pengukuran secara eksak/ matematis tidak mungkin dilakukan dalam penilaian kinerja, karena obyeknya adalah perilaku manusia bersifat unik dan kompleks. Penilaian kinerja disarankan sebagai format yang efektif untuk menilai kemajuan siswa dalam mencapai standar yang diarahkan pada tujuan, penggunaan multi keterampilan dan integrasi dari isinya. Pemimpin dapat melakukan penilaian dengan tepat dan mengkaji kinerja secara teratur, sistematis dan konsisten. Sugiyono (2009), menyatakan bahwa penilaian kinerja meliputi indikator sebagai berikut: 1) kualitas kerja; 2) kuantitas kerja; 3) etika kerja; 4) kreatifitas kerja; 5) pengetahuan kinerja; 6) kemandirian; 7) tanggung jawab.

\section{Metodologi Penelitian}

Penelitian ini dilakukan di Kabupaten Bengkulu Tengah selama 4 bulan. Penelitian ini menggunakan metode penelitian kuantitatif bersifat korelasional. Pendekatan penelitian digunakan penelitian kuantitatif merupakan penyederhanaan kompleksitas gejala dengan mereduksi kedalam ukuran yang yang ditangani dan diukur (Purwanto, 2006:72). Fokus dari penelitian ini adalah upaya menganalisis tentang absensi finger print terhadap peningkatan kinerja guru tersertifikasi di Kabupaten Bengkulu Tengah. Penelitian ini diharapkan dapat menjadi masukan yang berarti bagi Kementerian Agama Kabupaten Bengkulu Tengah dalam rangka meningkatkan kualitas kinerja guru madrasah serta kualitas madrasah secara keseluruhan. Populasi dalam penelitian ini adalah guru tersertifikasi di Kabupaten Bengkulu Tengah berjumlah 20 orang PNS. 
Sampel penelitian ini adalah guru tersertifikasi di Kabupaten Bengkulu Tengah yang berjumlah 20 orang (Suharsini Arikunto, 1998: 120).

Alat pengumpul data yang digunakan berbentuk kuesioner atau angket. Metode ini juga sering disebut intervew tertulis dimana responden dihubungi lewat daftar pertanyaan tertulis mengenai pendapat, keyakinan dan kesan pribadinya (Winarno Surachmad, 2000). Kuesioner dalam penelitian ini berupa butir-butir pernyataan yang berusaha mengungkap variabel absensi finger print (X). Kuesioner dalam penelitian ini berupa butir-butir pernyataan yang berusaha mengungkap variabel kinerja guru (Y). Berikut ini daftar pernyataan kuisioner persepsi finger print :

Tabel 1. Daftar pernyataan kuisioner persepsi finger print

\begin{tabular}{|c|c|c|c|}
\hline NO & PERNYATAAN & 25 & Meningkatkan produktivitas penghitungan \\
\hline 1 & Finger print sebagai sistem absensi yang akurat & 26 & Mampu melakukan pelaporan otomatis \\
\hline 2 & Finger print menunjukkan kedisiplinan yang tinggi & 27 & Semua aktifitas guru tercatat dengan jelas \\
\hline \multirow[t]{2}{*}{3} & \multirow{2}{*}{$\begin{array}{l}\text { Finger print sebagai cara untuk memudahkan para } \\
\text { pegawai dalam melakukan presensi }\end{array}$} & 28 & Mampu meingkatkan kedisiplinan \\
\hline & & 29 & Bekerja dengan penuh kreatif dan inisiatif. \\
\hline 4 & Finger print belum mampu mendeteksi kehadiran & 30 & $\begin{array}{l}\text { Bekerja dengan jujur, penuh semangat dan tanggung } \\
\text { jawab. }\end{array}$ \\
\hline 5 & Menghindari manipulasi data presensi & 31 & Proses data kehadiran cepat \\
\hline \multirow[t]{2}{*}{6} & \multirow{2}{*}{$\begin{array}{l}\text { Finger print cukup akurat, aman, mudah dan } \\
\text { nyaman untuk dipakai sebagai identifikasi }\end{array}$} & 32 & Mudah serta cara penggunaan yang sangat mudah \\
\hline & & 33 & Tidak menimbulkan kesalahan \\
\hline 7 & Mampu menunjang kelancaran pelaksanaan tugas & 34 & Tidak dapat dimanipulasi \\
\hline 8 & Pendisiplinan dilakukan secara pribadi & 35 & Mengurangi antri \\
\hline 9 & Pendisiplinan harus bersifat membangun. & 36 & Pencatatan kehadiran sesuai waktu kedatangan \\
\hline \multirow[t]{2}{*}{10} & \multirow{2}{*}{$\begin{array}{l}\text { Pendisiplinan dilakukan oleh atasan langsung } \\
\text { dengan segera. }\end{array}$} & 37 & Finger print sebagai tekhnologi universal \\
\hline & & \multirow[t]{2}{*}{38} & \multirow{2}{*}{$\begin{array}{l}\text { Finger print mampu mendeteksi ketidakhadiran } \\
\text { guru }\end{array}$} \\
\hline 11 & Keadilan dalam pendisiplinan sangat diperlukan. & & \\
\hline \multirow[t]{2}{*}{12} & \multirow{2}{*}{$\begin{array}{l}\text { Pimpinan hendaknya tidak seharusnya memberikan } \\
\text { pendisiplinan }\end{array}$} & 39 & Finger print memberikan kenyamanan bagi guru \\
\hline & & 40 & Finger print bekerja secara efektif dan efisien \\
\hline 13 & Menghindari kecurangan & & \\
\hline 14 & Menghindari guru pulang lebih cepat & & \\
\hline 15 & Menghindari kecurangan guru titip absen & & \\
\hline 16 & Setiap kecurangan tercatat dengan baik & & \\
\hline 17 & Tingkat kehadiran guru terpantau dengan baik & & \\
\hline 18 & Guru tidak mudah meninggalkan sekolah & & \\
\hline 19 & Meningkatkan Kinerja Instansi & & \\
\hline 20 & Mengoptimalkan Jam Kerja guru & & \\
\hline 21 & $\begin{array}{l}\text { Disiplin kerja tidak semata-mata patuh dan taat } \\
\text { terhadap penggunaan jam kerja, misalnya datang } \\
\text { dan pulang sesuai tidak mangkir saat bekerja. }\end{array}$ & & \\
\hline 22 & $\begin{array}{l}\text { Upaya dalam mentaati peraturan tidak didasarkan } \\
\text { adanya perasaan takut, atau terpaksa. }\end{array}$ & & \\
\hline 23 & $\begin{array}{l}\text { Komitmen dan loyal pada organisasi yaitu tercrmin } \\
\text { dari bagaimana sikap dalam bekerja. }\end{array}$ & & \\
\hline 24 & $\begin{array}{l}\text { Melaksanakan dan menyelesaikan tugas pada } \\
\text { waktunya }\end{array}$ & & \\
\hline
\end{tabular}


Jurnal As-Salam Vol.2(3). 2018: 71-79

Carona Elianur

Tabel 2. Daftar pernyataan kuisioner persepsi kinerja guru:

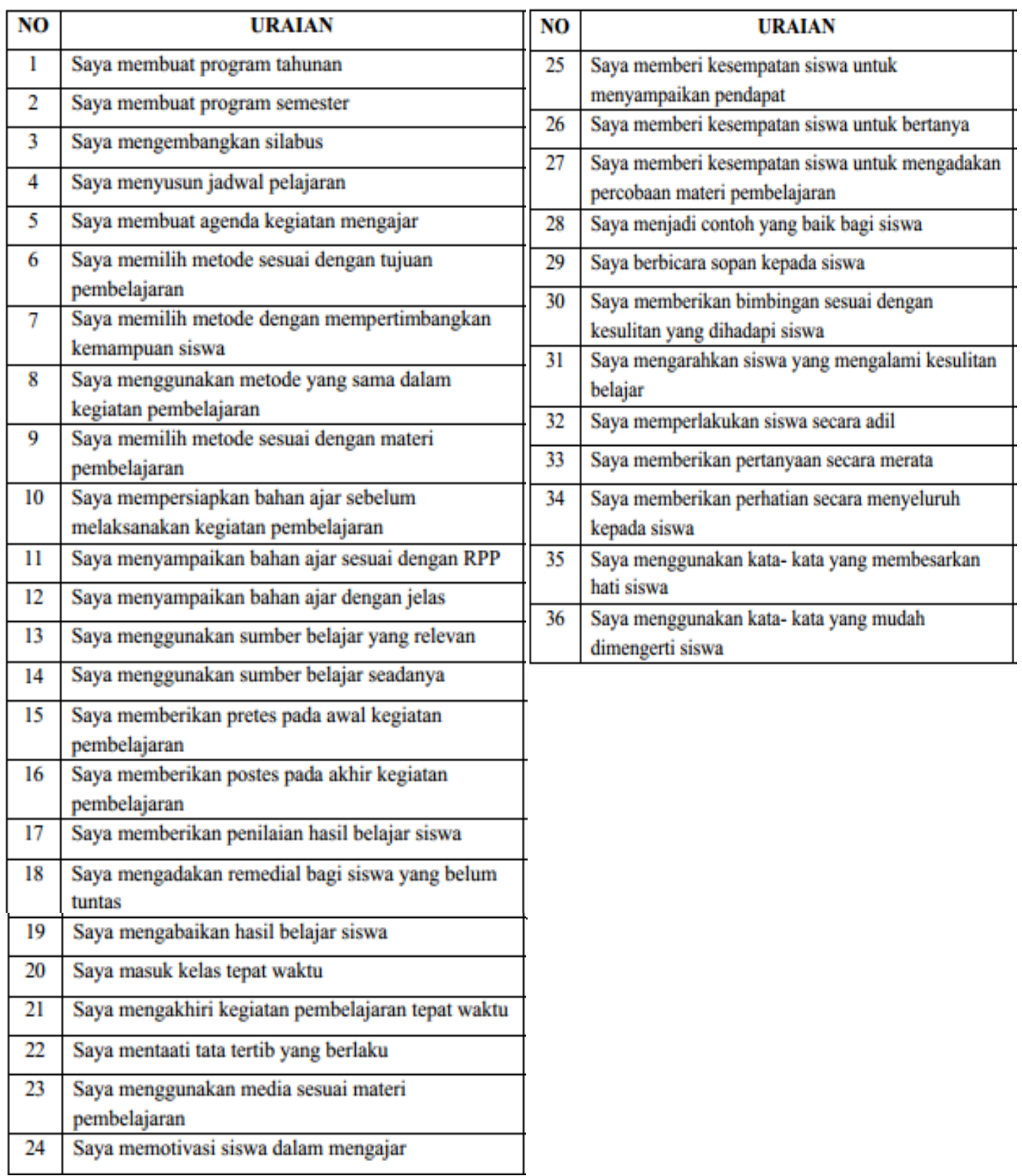

Data yang dikumpulkan melalui metode pengumpulan data yang digunakan mempunyai arti apabila diolah dan dianalisis. Dari awal analisa tersebut, maka akan dapat dinterpretasikan, dan selanjutnya dapat dirumuskan kesimpulan akhir dari suatu penelitian.

a) Uji Normalitas

Uji normalitas bertujuan untuk menguji apakah dalam model regresi variabel terikat dan variabelbebas keduanya mempunyai distribusi normal ataukah tidak (Ghozali, 2005: 76). Untuk uji normalitas data hasil tes digunakan uji Kolmogorow Smirnov (Prosedur Explorer pada menu utama SPSS) dan melihat normal probability plotmelalui tampilan output SPSS 16.0. 
b) Uji Linearitas atau Keberartian Regresi

Uji linieritas dimaksudkan untuk mengetahui apakah masingmasing variabel yang dijadikan prediktor mempunyai hubungan yang linier atau tidak terhadap variabel terikatnya. Pengujian linieritas dalam penelitian ini menggunakan uji LM (legrang multiplier). Kriteria dalam pengujian linieritas ini adalah apabila nilai $\mathrm{C}^{2}$ atau LM ( $\left.\mathrm{R}^{2} \mathrm{x} \mathrm{N}\right)<\mathrm{C}^{2}$ tabel maka data linier (Ghozali, 2005: 118).

c) Uji Hipotesis

Adapun hipotesis dari penelitian ini yaitu:

1. Ho : absensi finger print tidak berpengaruh terhadap kinerja guru tersertifikasi di Kabupaten Bengkulu Tengah

2. Ha : absensi finger print berpengaruh terhadap kinerja guru tersertifikasi di Kabupaten Bengkulu Tengah

Adapun untuk mengetahui hubungan manajemen finger print terhadap peningkatan kinerja guru tersertifikasi di Kabupaten Bengkulu Tengah digunakan rumus teknik korelasi product moment adalah sebagai berikut (Arikunto, 2006: 170):

$$
r_{x Y}=\frac{N \Sigma X Y-(\Sigma X)(\Sigma Y)}{\sqrt{\left[N \Sigma X^{2}-\left(\Sigma X^{2}\right)\right]\left[N \Sigma Y^{2}-\left(\Sigma Y^{2}\right)\right]}}
$$

Keterangan:

$\mathrm{X}$ : Skor total absensi finger print

$\mathrm{Y}$ : Skor total kinerja guru

$\mathrm{N}$ : Jumlah responden

Kriteria pengambilan keputusan:

a) Jika signifikansi $>0,05$ maka Ho diterima

b) Jika signifikansi $<0,05$ maka Ho ditolak

\section{Hasil Penelitian Dan Pembahasan}

Penelitian ini dilakukan pada guru-guru yang telah tersertifikasi di Kementerian Agama Bengkulu Tengah yang berjumlah 20 orang. Berdasarkan dari penelirian yang telah dilakukan, didapat data skor kuisioner masing-masing variable sebagai berikut:

Tabel 3. Statistik Data Penelitian

\begin{tabular}{ccccc}
\hline & $\begin{array}{c}\text { Jumlah } \\
\text { Responden }\end{array}$ & Minimum & Maksimum & Rata-rata \\
\hline Absensi Finger Print (X) & 20 & 134 & 148 & 138.8 \\
Kinerja Guru (Y) & 20 & 109 & 115 & 112.5 \\
\hline
\end{tabular}

1. Persepsi guru terhadap Absensi Finger Print

Berdasarkan tabel statistik data penelitian di atas menunjukkan bahwa variabel absensi finger print (X) dari responden 20 mempunyai skor minimal 134 dan maksimal 148. Hasil deskripsi data menunjukkan nilai rata-rata sebesar 138.8. Berikut ini grafik data Absensi Finger Print: 
Tabel 4. grafik data Absensi Finger Print

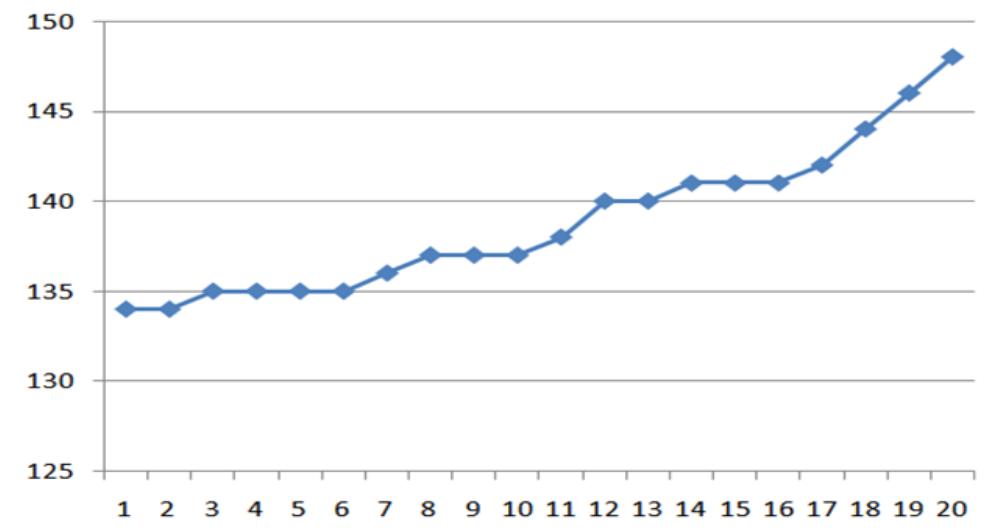

Apabila dijabarkan hasil angket, didapat fakta sebagai berikut:

a) Pernyataan Finger print sebagai sistem absensi yang akurat, hanya 7 orang yang menjawab sangat setuju, sedangkan 13 orang menjawab setuju. Dari hasil ini dapat dilihat bahwa tidak semua guru sangat yakin bahwa absensi finger print merupakan sistem yang akurat.

b) Pernyataan Finger print menunjukkan kedisiplinan yang tinggi, menghasilkan jawaban 7 orang menjawab sangat setuju, sedangkan yang lainnya berjumlah 13 orang menjawab setuju. Pada pernyataan ini juga terlihat bahwa kebanyakan guru tidak sangat setuju bahwa absensi Finger print merupakan alat penunjuk kedisiplinan tinggi.

c) Pernyataan Menghindari manipulasi data presensi, didapat skor yang sangat tinggi yaitu skor maksimum, hal ini menunjukkan bahwa semua guru sangat setuju bahwa absensi Finger Print dapat menghindari manipulasi.

d) Pernyataan Saya memberikan perhatian secara menyeluruh kepada siswa, merupakan pernyataan dengan nilai paling rendah yaitu total 60 , disini semua guru hanya menjawab setuju.

\section{Kinerja Guru (Y)}

Berdasarkan tabel statistik data penelitian di atas tentang statistik deskriptif data penelitian khususnya tentang kinerja guru menunjukkan skor data berkisar antara 109115. Dari hasil stasitik deskriptif diperoleh nilai rata-rata sebesar 115.5. Berikut ini grafik data Kinerja Guru:

Tabel 5. grafik data kinerja guru

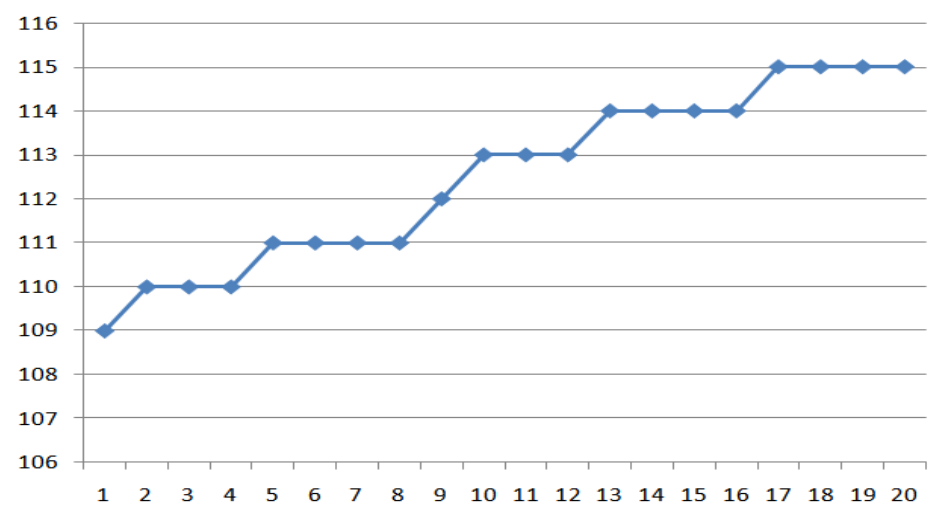


Apabila dijabarkan hasil angket, didapat fakta sebagai berikut:

a) Pernyataan Saya mengembangkan silabus, didapat hasil jumlah skor sebesar 60 , hal ini menunjukkan bahwa guru hanya setuju untuk mengembangkan silabus tapi tidak ada guru yang menjawab sangat setuju. Nilai sama juga didapat pada pernyataan-pernyataan: Saya menyusun jadwal pelajaran, Saya mempersiapkan bahan ajar sebelum melaksanakan kegiatan pembelajaran, Saya menyampaikan bahan ajar sesuai dengan RPP, Saya menyampaikan bahan ajar dengan jelas, dan Saya menggunakan kata- kata yang membesarkan hati siswa.

b) Pernyataan Saya menggunakan kata-kata yang mudah dimengerti siswa, merupakan pernyataan yang mendapat skor paling tinggi, yaitu 71, hal ini menunjukkan bahwa dari semua pernyataan tentang kinerja guru, pernyataan ini merupakan pernyataan yang paling banyak disetujui oleh guru.

3. Uji Hipotesis

Untuk menguji hipotesis penelitian menggunakan bantuan aplikasi spss 16.0. hasil pengujian didapat data sebagai berikut.

\section{Correlations}

\begin{tabular}{|ll|r|r|}
\hline & & Absensi & Kineria_guru \\
\hline Absensi & Pearson Correlation & 1 & .287 \\
& Sig. (2-tailed) & & .220 \\
& $\mathrm{~N}$ & 20 & 20 \\
\hline Kinerja_guru & Pearson Correlation & .287 & 1 \\
& Sig. (2-tailed) & .220 & \\
& $\mathrm{~N}$ & 20 & 20 \\
\hline
\end{tabular}

Signifikansi yang didapat sebesar 0.220 berarti lebih > 0,05 sehingga Ho diterima, jadi absensi finger print tidak berpengaruh terhadap kinerja guru tersertifikasi di Kabupaten Bengkulu Tengah.

\section{Kesimpulan}

Berdasarkan hasil penelitian, maka didapat kesimpulan sebagai berikut:

1. Persepsi absensi finger print guru tersertifikasi di Kabupaten Bengkulu Tengah berada pada tingkatan baik dengan rata-rata skor 138.8.

2. Kinerja guru tersertifikasi di Kabupaten Bengkulu Tengah berada pada tingkatan baik dengan rata-rata skor 112.8.

3. Persepsi absensi finger print tidak berpengaruh terhadap kinerja guru tersertifikasi di Kabupaten Bengkulu Tengah.

\section{Daftar Pustaka}

Handoko, T. Hani 2001. Manajemen Personalia \& Sumberdaya Manusia. Yogyakarta: BPFE.

Heriawanto. 2004. Analisis Faktor-Faktor yang Mempengaruhi Motivasi Kerja Karyawan Magister Manajemen Agribisnis Institut Pertanian Bogor. Bogor: Skripsi Departemen Ilmu-Ilmu Sosial Ekonomi Pertanian Fakultas Pertanian IPB.

Muhammad, A. 2001. Komunikasi Organisasi. Ed. 1, Cet.4 Jakarta: Bumi Aksara. 
Purwanto, 2011. Statistika untuk Penelitian. Yogyakarta : Pustaka Pelajar

Simamora, Henry, 2006. Manajemen Sumber Daya Manusia. Yogyakarta: STIE YKPN.

Sugiyono, 2009. Statistika Untuk Penelitian. Bandung. Alfabeta

Suharsimi Arikunto, Prosedur Penelitian: Suatu Pendekatan Praktek. Jakarta: Rineka Cipta, 2008.

Sulistyorini, 2001. Hubungan antara Keterampilan Manajerial Kepala Sekolah dan Iklim Organisasi dengan Kinerja Guru. Ilmu Pendidikan: 28 (1) 62-70.

Surakhmad, Winarno. 2000. Pengantar Penelitian Ilmiah Dasar Metode Teknik. Bandung: Tarsito

Tempe, A. Dale., 1992. Kinerja. Jakarta : PT. Gramedia Asri Media.

Widhyarini, 2010. Analisis dan perancangan sistem presensi karyawan menggunakan sidik jari di ABA YIPK Yogyakarta. Sekolah tinggi menejemen informatika dan komputer Amikom Yogyakarta. Tidak dipublikasikan. 